\title{
PENDAMPINGAN PENYUSUNAN PERATURAN DESA TENTANG PENGELOLAAN JARINGAN IRIGASI DESA NDANO
}

\author{
Munir Husen ${ }^{1}$, Adnan $^{2}$, Syahrullah ${ }^{3,}$ Kaharudin $^{4}$, Sultan Sangaji ${ }^{5}$, Anton $^{6}$, Inayah Wulandari ${ }^{7}$, dan Putri \\ Andriani $^{8}$ \\ ${ }^{1}$ Sekolah Tinggi Ilmu Hukum Muhammadiyah Bima, Kota Bima-Indonesia \\ ${ }^{2}$ Sekolah Tinggi Ilmu Hukum Muhammadiyah Bima Kota Bima-Indonesia \\ ${ }^{3}$ Sekolah Tinggi Ilmu Hukum Muhammadiyah Bima, Kota Bima-Indonesia \\ ${ }^{4}$ Sekolah Tinggi Ilmu Hukum Muhammadiyah Bima, Kota Bima-Indonesia \\ ${ }^{5}$ Sekolah Tinggi Ilmu Hukum Muhammadiyah Bima, Kota Bima-Indonesia \\ ${ }^{6}$ Sekolah Tinggi Ilmu Hukum Muhammadiyah Bima, Kota Bima-Indonesia \\ ${ }^{7}$ Sekolah Tinggi Ilmu Hukum Muhammadiyah Bima, Kota Bima-Indonesia \\ ${ }^{8}$ Sekolah Tinggi Ilmu Hukum Muhammadiyah Bima, Kota Bima-Indonesia \\ Email : Email: syahab513@gmail.com
}

\begin{abstract}
Abstrak
Desa Ndano, merupakan salah satu desa yang terletak di Kecamatan Madapangga, Kabupaten Bima, Provinsi Nusa Tenggara Barat, merupakan kawasan pertanian tanaman pangan dan holtikultura. Permasalahan yang paling utama yang dihadapi dalam pengelolaan irigasi saat ini adalah masalah kelembagaan dan pembiayaan, antara lain: (a) Kebutuhan air untuk mengairi persawahan utamanya padi, belum optimal didukung oleh irigasi yang memadai; (b) Kepengurusan P3A belum diatur secara tegas dalam Peraturan Desa ataupun Peraturan Kepala Desa; (c) Kemauan untuk membayar iuran sangatlah rendah; (c) Ada iuga beberapa warga yang kemampuan untuk membayar rendah; dan (d) Aspek majanerial P3A masih rendah. Solusi yang hendak dikerjakan adalah (a) Memfasilitasi Menyusun Peraturan Desa yang mengatur kelembagaan P3A dan tatacara dan besarnya pungutan iuran pemakaian air; (b) Memberikan bimbingan teknis tentang tatacara penyusunan peraturan di desa. Adapun rencana kegiatan antara lain: (a) Rapat Persiapan; (b) Pengumpulan bahan; (c) Studi lapangan; (d) Penyusunan Konsep Rancangan Perdes; (e) Rapat Pembahasan Konsep Rancangan Perdes; (f) Perumusan Rancangan Perdes; (g) Rapat Konsultasi dengan Masyarakat, Camat dan Pemkab Bima; dan (h) Penyusunan naskah final Rancangan Perdes.

Kata Kunci: Peraturan, desa, iuran Pemakai Air
\end{abstract}

\section{PENDAHULUAN}

Desa Ndano, merupakan salah satu desa yang terletak di Kecamatan Madapangga, Kabupaten Bima, Provinsi Nusa Tenggara Barat, merupakan kawasan pertanian tanaman pangan dan holtikultura. Desa Ndano terletak di kawasan mata air madapangga. Beriklim tropis dengan jumlah curah hujan rata-rata adalah 1091 $\mathrm{mm}$, dan hari hujan ratarata ... hari hujan. Suhu udara rata-rata ....oC dengan kelembaban ratarata ...\%. Bulan basah antara 8-10 bulan dan bulan kering 2-4 bulan Banyak lahan di desa digunakan sebagai lahan pertanian atau perkebunan. Masyarakat Desa Ndano banyak yang bekerja sebagai petani. Jumlah penduduk Desa Ndano sebesar 1.677 jiwa dengan jumlah Kepala Keluarga 540 Penduduk yang laki-laki berjumlah 828 jiwa dan perempuan sejumlah 849 jiwa. Pertanian adalah kegiatan pemanfaatan sumber daya hayati yang dilakukan manusia untuk menghasilkan bahan pangan, bahan baku industri, atau sumber energi, serta untuk mengelola lingkungan hidupnya. Kegiatan pemanfaatan sumber daya hayati yang termasuk dalam pertanian biasa dipahami orang sebagai budidaya tanaman, meskipun cakupannya dapat pula berupa pemanfaatan mikroorganisme dan bioenzim dalam pengolahan produk lanjutan, seperti pembuatan keju dan tempe, atau sekadar ekstraksi semata, seperti penangkapan ikan atau eksploitasi hutan.

Irigasi adalah usaha penyediaan dan pengaturan air untuk memenuhi kebutuhan

Ekonomi, Sosial, dan Budaya | 1377 
pertanian dan bissa dipergunakan untuk keperluan lain seperti air baku, penyediaan air minum, pembangkit listrik, keperluan industri, perikanan, ataupun untuk penggelontoran air. Murdiana \& Fadli (2016), irigasi merupakan salah satu faktor penting dalam produksi padi sawah. Irigasi sebagai sumber bagi ketersediaan air untuk pertumbuhan tanaman padi. Persediaan air yang mencukupi tentu sangat berpengaruh dalam peningkatan produksi padi sawah. Petani di jaringan irigasi setiap musim tanamnya dipungut Iuran Pengelolaan Irigasi (IPI) oleh petugas. Kontribusi petani dalam IPI agar dapat berpartisipasi dalam pembiayaan operasi dan pemeliharaan jaringan irigasi (Noovry \& Suhudi, 2009). Syaukat dkk. (2014), menyatakan sistem harga air irigasi saat ini seperti Iuran Pengelolaan Irigasi (IPI) dapat dikembangkan untuk masa yang akan datang. Pungutan IPI ini pun masih beragam perolehannya dan umumnya masih relatif rendah. Hal yang sama juga dikemukan oleh Isharyanto dkk. (2016), bahwa pembiayaan pengelolaan irigasi oleh kelembagaan petani irigasi secara keseluruhan masih sangat terbatas kemampuan penyediaan dana operasi dan pemeliharaan jaringan irigasinya bila dibandingkan dengan kebutuhan pemeliharaan jaringan irigasi yang harus dikelola.

IPI dalam konteks metode harga air termasuk ke dalam per unit area pricing (Sumaryanto, 2006). Petani harus membayar iuran didasarkan pada luas areal lahan usaha tani dalam satu area irigasi dalam satu Daerah Irigasi. IPI ditentukan berdasarkan kesepakatan bersama antara para petani dan petugas yang mewakili pengurus $\mathrm{P} 3 \mathrm{~A}$ atau desa biasanya oleh ulu-ulu yang bertugas memungut IPI per musimnya. IPI ditentukan atas luas lahan yang diusahakannya per musim tanam dengan diukur oleh kuantitas GKP (kg/ha) dikalikan dengan nilai harga HKP per musim tanam sehingga IPI senilai Rp/ha per musim tanam. IPI berguna untuk menghimpun dana operasional pemeliharaan dan perbaikan irigasi yang menjadi tanggung jawab para petani, sehingga petani dituntut untuk peran dan partisipasinya dalam membayar IPI per musim tanam.

Permasalahan yang paling utama yang dihadapi desa Ndano kecamatan Madapangga Kabupaten Bima, dalam pengelolaan irigasi saat ini adalah masalah kelembagaan dan pembiayaan. Untuk itu berikut ini dikemukakan permasalahan mitra antara lain: Pertama Kebutuhan air untuk mengairi persawahan utamanya padi, belum optimal didukung oleh irigasi yang memadai. Saluran irigasi yang ada mengalami pendangkalan, kerusakan di sana sini sehingga debit air yang tertampung belum mencukupi kebutuhan para petani. Kedua Kepengurusan P3A belum diatur secara tegas dalam Peraturan Desa ataupun Peraturan Kepala Desa. Prakteknya selama ini hanya berdaarkan hasil Rapat kemudian di tunjuk pengurus yang mengelola air irigasi termasuk untuk menagih iuran pemakai air. Ketiga Kemauan untuk membayar iuran sangatlah rendah, karena faktor kepercayaan kepada pengurus yang rendah, Ada iuga beberapa warga yang kemampuan untuk membayar rendah dan aspek majanerial P3A masih rendah.

\section{METODE}

Kegiatan PKM ini akan dilaksanakan selama 3 (tiga) bulan di tahun 2021 (Juli - September) yang terbagi ke dalam 7 (tujuh) tahapan yaitu:

1. Tahap Persiapan

Tahap persiapan terdiri dari dua, persiapan pengusul dan persiapan lapangan. Tim pengusul mengadakan pertemuan antar anggota Tim untuk menyamakan persepsi dan menentukan urutan kegiatan yang akan dilaksanakan. Sedangkan persiapan lapangan dilakukan melalui studi kelayakan terhadap daerah yang akan dijadikan sebagai mitra, baik dilakukan secara formal maupun informal. Bila sudah ditemukan mitra yang ingin dikembangkan, pengusul harus mencoba menerobos jalur formal untuk mendapat perizinan dari pihak terkait. Di samping itu, pengusul juga harus menjalin kontak dengan tokoh-tokoh informal agar

Ekonomi, Sosial, dan Budaya | 1378 
hubungan dengan masyarakat dapat terjalin dengan baik.

2. Tahap pengkajian, yaitu melakukan identifikasi masalah atau kebutuhan yang diekspresikan dan sumber daya yang dimiliki mitra. Mitra dilibatkan secara aktif agar permasalahan yang keluar adalah dari pandangan mereka sendiri, dan pengusul memfasilitasi mitra untuk menyusun prioritas dari permasalahan yang mereka sampaikan. Hasil pengkajian ini akan ditindaklanjuti pada tahap berikutnya, yaitu tahap perencanaan Tahap pengkajian dilakukan dengan Focus Group Discution (FGD).

3. Tahap perencanaan alternatif kegiatan

Pada tahap ini pengusul secara partisipatif mencoba melibatkan mitra untuk berpikir tentang masalah yang mereka hadapi, bagaimana cara mengatasinya serta memikirkan beberapa alternative program dan kegiatan yang dapat dilakukan.

4. Tahap formulasi rencana aksi

Pada tahap ini pengusul membantu mitra untuk merumuskan dan menentukan program dan kegiatan apa yang akan mereka lakukan guna mengadaptasi permasalahan yang ada.

5. Tahap inplementasi kegiatan

Tahap pelaksanaan terdiri dari:

- Rapat Persiapan;

- Pengumpulan bahan;

- Studi lapangan;

- Penyusunan Konsep Rancangan Perdes;

- Rapat Pembahasan Konsep Rancangan Perdes

- Perumusan Rancangan Perdes

- Rapat Konsultasi dengan Masyarakat, Camat dan Pemkab Bima;

- Penyusunan naskah final Rancangan Perdes

6. Tahap evaluasi

Evaluasi dimaksudkan untuk memberikan umpan balik bagi perbaikan kegiatan.

7. Tahap terminasi

Tahap ini merupakan tahap 'perpisahan' hubungan secara formal dengan mitra.

\section{HASIL DAN PEMBAHASAN}

Pelaksanaan kegiatan Pengabdian kepada Masyarakat dengan judul : Pendampingan Penyusunan Peraturan Desa Tentang Pengelolaan Jaringan Irigasi Desa Ndano, dimulai dari bulan Juli sampai pada bulan September 2021. Bersamaan pula dengan pelaksanaan Kuliah Kerja Nyata (KKN) tematik Sekolah Tinggi Ilmu Hukum (STIH) muhammadiyah Bima angkatan ke XXI, telah dilaksanakan $100 \%$. Program dilaksanakan dengan pendampingan dan beberapa kali tatap muka. Kegiatan pengabdian masyarakat ini dilakukan dalam bentuk transfer iptek untuk menyelesaikan permasalahan yang dihadapi oleh mitra dalam kaitannya dengan upaya pengembangan wawasan pengetahuan dan keterampilan penyusunan peraturan ditingkat desa Ndano Kecamatan Madapangga Kabupaten Bima, yaitu berupa : (1) Memfasilitasi Menyusun Peraturan Desa yang mengatur kelembagaan P3A dan tatacara dan besarnya pungutan iuran pemakaian air; dan (2) Memberikan bimbingan teknis tentang tatacara penyusunan peraturan di desa.

Adapun alur pelaksanaan program PKM ini dimulai dari:

Tahap pelaksanaan terdiri dari: Rapat Persiapan; Rapat persiapan dilaksanakan pada 5 Juli 2021. Pengumpulan bahan; Pengumpulan bahan-bahan yang berkaitan langsung dengan penyusunan perdes seperti Peraturan perundangundangan, naskah-naskah jurnal dan juklak juknis. Studi lapangan; Studi lapangan diarahkan pada beberapa responden berkaitan dengan materi muatan perdes masalah yang dihadapi di tengah masyarakat desa ndano. Pada tahap ini dapat diidentifikasi beberapa maslaha yang akan diatur dalam Perdes. Termasuk yang berkembang ada dua materi, yaitu (1) sebagagian masyarakat berkehendak untuk menyusun Perdes tentang pengelolaan air bersih untuk konsumsi (2) sebagiannya bagaimana mengatur pembagian air untuk irigasi, karena deposit air semakin berkurang; jaringan irigasi yang rusak dan lain-lain.

Penyusunan Konsep Rancangan Perdes; Dari berbagai masukan dan pandangan pada di putuskan bahwa pengelolaan irigasi desa yang lebih prioritas.Namun sebelum di rumuskan

Ekonomi, Sosial, dan Budaya | 1379 
Perdes, di adakan bimbingan teknis tentang Tatacara Penyusunan Produk Hukum di tingkat Desa. Pada tanggal 24-25 Juli 2021 diadakan bimbingan teknis Penyusunan Perdes. Dengan materi:

- Penyelenggaraan Pemerintahan Desa oleh H. Adnan,SH,MH

- Teknis Penyusunan Peraturan Desa oleh Munir Husen, SH, MH

- Praktek Penyusunan Peraturan Desa, oleh Syahrullah, SH MH

- Rapat Pembahasan Konsep Rancangan Perdes

Rapat pembahasan konsep rancangan Perdes dilaksanakan pada tanggal 26 Juli 2021. Perumusan Rancangan Perdes Perumusan Rancangan Perdes dimulai 26 juli s/d 28 Juli 2021. Rapat Konsultasi dengan Masyarakat, Camat dan Pemkab Bima; Setelah naskah rancangan perdes telah disusun, maka diadakan rapat konsultasi dengan masyarakat pada tanggal 2 Agustus 2021. Rapat ini untuk mendapat masukan dari masyarakat terutama petani pemakai air, unsur kecamatan dan Pemerintah Kabupaten. Penyusunan naskah final Rancangan Perdes. Selanjutnya dari tanggal 3 s/d 5 Agustus 2021 penyusunan naskah final.

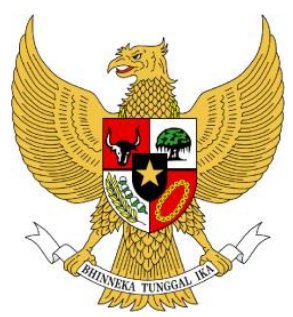

KEPALA DESA NDANO

KABUPATEN BIMA

RANCANGAN PERATURAN DESA NDANO

NOMOR TAHUN 2021

TENTANG

PENGELOLAAN JARINGAN IRIGASI DESA NDANO
DENGAN RAHMAT TUHAN YANG MAHA ESA

KEPALA DESA NDANO,

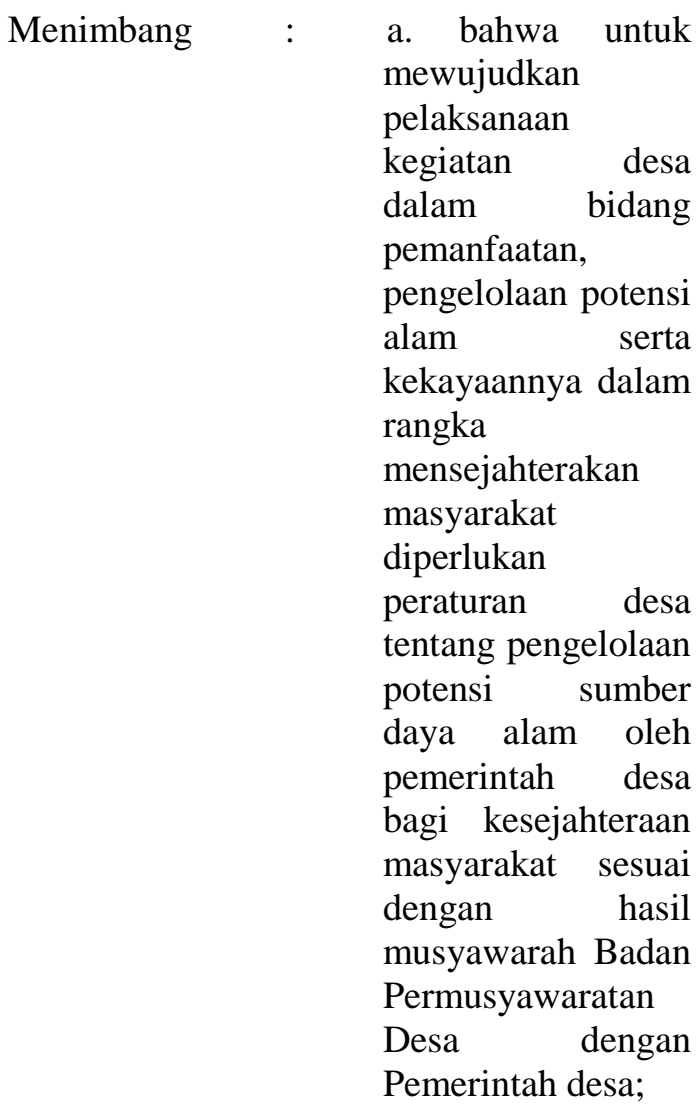

b. bahwa oleh karena itu perlu diatur dan ditetapkan dengan Peraturan

Desa Ndano.

Mengingat : 1 . Undang-Undang Nomor 69 Tahun 1958 tentang Pembentukan

Daerah-daerah

Tingkat II dalam Daerah-daerah

Tingkat I Bali, Nusa Tenggara Barat dan Nusa Tenggara Timur (Lembaran Negara Republik Indonesia Tahun 1958 Nomor

Ekonomi, Sosial, dan Budaya | 1380 
122, Tambahan

Lembaran Negara

Republik Indonesia

Nomor 1655);

2. Undang-Undang

Nomor 6 Tahun

2014 tentang Desa

(Lembaran Negara

Republik Indonesia

Tahun 2014 Nomor

7, Tambahan

Lembaran Negara

Republik Indonesia

Nomor 5495);

3. Undang-Undang

Nomor 23 Tahun

2014 tentang

Pemerintahan

Daerah (Lembaran

Negara Republik

Indonesia Tahun

2014 Nomor 244,

Tambahan

Lembaran Negara

Republik Indonesia

Nomor 5587),

sebagaimana telah

diubah beberapa

kali, terakhir

dengan Undang-

Undang Nomor 9

Tahun 2015 tentang

Perubahan Kedua

atas Undang-

Undang Nomor 23

Tahun 2014 tentang

Pemerintahan

Daerah (Lembaran

Negara Republik

Indonesia Tahun

2015 Nomor 58,

Tambahan

Lembaran Negara

Republik Indonesia

Nomor 5679);

4. Undang-Undang Nomor 12 Tahun 2011 tentang Pembentukan
Peraturan Perundangundangan (Lembaran Negara Republik Indonesia Tahun 2011 Nomor 82, Tambahan Lembaran Negara Republik Indonesia Nomor 5234);

5. Peraturan Pemerintah Nomor 43 Tahun 2014 tentang Peraturan Pelaksanaan UndangUndang Nomor 6 Tahun 2014 tentang Desa (Lembaran Negara Republik Indonesia Tahun 2019 Nomor 41 Tambahan Lembaran Negara Republik Indonesia Nomor 6321) sebagaimana telah diubah beberapa kali terakhir Peraturan Pemerintah Nomor 11 Tahun 2019 tentang Perubahan kedua Peraturan Pemerintah Nomor 43 Tahun 2014 tentang Peraturan Pelaksana UndangUndang Nomor 6 Tahun 2014 tentang Desa ( Lembaran Negara Republik Indonesia Tahun 2019 Nomor 41, Tambahan Lembaran Negara Republik Indonesia Nomor 6321);

6. Peraturan Pemerintah Nomor 12 Tahun 2017 tentang Pembinaan dan Pengawasan

Penyelenggaraan

Pemerintah Daerah (Lembaran Negara Republik Indonesia

Ekonomi, Sosial, dan Budaya | 1381 


\begin{abstract}
Tahun 2017 Nomor
73, Tambahan

Lembaran Negara

Republik Indonesia

Nomor 6041);
\end{abstract}

7. Peraturan Menteri Dalam Negeri Nomor 111 Tahun 2014 tentang Pedoman Teknis Penyusunan Peraturan di Desa (Berita Negara Republik Indonesia Tahun 2014 Nomor 209)

8. Peraturan Menteri Dalam Negeri Republik Indonesia Nomor 80 Tahun 2015 tentang Pembentukan Produk Hukum Daerah (Berita Negara Republik Indonesia Tahun 2015 Nomor 2036);

9. Peraturan Menteri Dalam Negeri Nomor 44 Tahun 2016 tentang Kewenangan Desa (lembaran Negara Republik Indonesia Tahun 2016 Nomor 1037);

10. Peraturan Menteri Dalam Negeri Nomor 20 Tahun 2018 tentang Pengelolaan Keuangan Desa (Berita Negara Republik Indonesia Tahun 2018 Nomor 611);

11. Peraturan Bupati Bima Nomor 41 Tahun 2018 tentang Pedoman Penyusunan Produk Hukum Daerah (berita

\begin{tabular}{lrr} 
Daerah & \multicolumn{2}{r}{ Kabupaten } \\
Bima & Tahun 2018 \\
Nomor & 12. Peraturan \\
Bupati & Bima & Nomor 2 \\
Tahun & 2020 & tentang \\
Daftar & Kewenangan \\
Desa Berdasarkan Hak \\
Asal Usul ran \\
Kewenangan $r$ Lokal \\
Berskala & Desa & (Berita \\
Daerah & Kabupaten \\
Bima Tahun & 2020 \\
Nomor 546)
\end{tabular}

Dengan Persetujuan Bersama

BADAN PERMUSYAWARATAN DESA NDANO

Dan

KEPALA DESA NDANO

MEMUTUSKAN

Menetapkan

: PERATURAN DESA NDANO TENTANG PENGELOLAAN JARINGAN IRIGASI DESA NDANO

BAB I

\section{KETENTUAN UMUM}

\section{Pasal 1}

Dalam Peraturan desa ini yang dimaksud dengan

1. Daerah adalah Kabupaten Bima.

2. Pemerintah Daerah adalah Pemerintah Kabupaten Bima.

3. Bupati ialah Bupati Bima.

4. Kecamatan adalah Kecamatan Madapangga

5. Camat ialah Camat Madapangga.

6. Desa adalah Desa Ndano Kecamatan Madapangga Kabupaten Bima.

7. Pemerintahan Desa adalah penyelenggaraan urusan pemerintahan Ekonomi, Sosial, dan Budaya | 1382 
dan kepentingan masyarakat setempat dalam sistem pemerintahan di Kabupaten Bima.

8. Pemerintah Desa adalah Pemerintah Desa Ndano Kecamatan Madapangga Kabupaten Bima.

9. Badan Permusyawaratan Desa yang selanjutnya disingkat BPD adalah Badan Musyawarah Desa Ndano Kecamatan Madapangga Kapupaten Bima.

10. Peraturan Desa adalah peraturan perundang-undangan yang ditetapkan oleh kepala desa setelah dibahas dan disepakati bersama oleh BPD.

11. Iuran Pelayanan Irigasi yang selanjutnya disingkat IPAIR adalah iuran yang dipungut dari Petani Pemakai Air atas jasa pelayanan yang diberikan oleh Pemerintah Desa yang besarnya didasarkan atas musyawarah dengan Petani Pemakai Air;

12. Irigasi adalah usaha penyediaan dan pengaturan air untuk menunjang pertanian;

13. Jaringan Irigasi adalah saluran dan bangunan yang merupakan satu kesatuan dan diperlukan untuk pengaturan air irigasi mulai dari penyediaan, pengambilan, pembagian, pemberian,dan penggunaannya;

14. Jaringan Irigasi Kecil adalah jaringan irigasi dengan luas areal yang diairi kurang dari 500 (limaratus) hektar dan tercatat dalam Buku Inventarisasi Daerah Irigasi Dinas Pekerjaan Umum Kabupaten Bima;

15. Daerah Irigasi adalah kesatuan wilayah yang mendapat air dari satu jaringan irigasi;

16. Petani Pemakai Air adalah penggarap lahan yang dalam menjalankan usahanya mendapat air dari jaringan irigasi;

17. Perkumpulan Petani Pemakai Air yang selanjutnya disebut P3A adalah wadah perkumpulan dari petani atau kelompok tani yang mengelola air irigasi dalam suatu petak tersier atau daerah irigasi pedesaan
OPERASI DAN PEMELIHARAAN

JARINGAN IRIGASI

\section{Pasal 2}

Jaringan Irigasi beserta bangunan pelengkapnya mulai dari bangunan pengambilan sampai pada saluran tersier percontohan sepanjang 50 (limapuluh) meter sesudah bangunan sadap, termasuk jaringan irigasi kecil yang belum diserahkan kepada P3A, pelaksanaan operasi dan pemeliharaannya menjadi tugas dan tanggungjawab Pemerintah Daerah

\section{Pasal 3}

Untuk biaya operasi dan pemeliharaan jaringan irigasi dimaksud Pasal 2 Peraturan Daerah ini, Petani Pemakai Air di Daerah Irigasi diikutsertakan menanggung pembiayaannya dengan membayar IPAIR

\section{Pasal 4}

Daerah Irigasi dimaksud Pasal3 Peraturan Daerah ini adalah Daerah Irigasi yang telah siap dioperasi, meliputi:

a. Yang luasnya 500 (lima ratus) hektar atau lebih;

b. Yang luas nya kurang dari 500 (lima ratus) hektar, dan pengelolaannya belum diserahkan kepada P3A.

\section{$\mathrm{BAB} 3$}

\section{IURAN PEMAKAIAN AIR IRIGASI}

Bagian Pertama

Penetapan IPAIR

Pasal 5

(1) Besarnya IPAIR untuk masing-masing Daerah Irigasi ditetapkan dengan Keputusan Kepala Desa berdasarkan saran pertimbangan dari Badan Musyawarah IPAIR dengan memperhatikan hal-hal sebagai berikut:

Ekonomi, Sosial, dan Budaya | 1383 
a. Kebutuhan nyata pembiayaan operasi dan pemeliharaan jaringan irigasi yang bersangkutan;

b. Keadaan social ekonomi petani;

c. Kelangkaan air tiap musim;

d. Keandalan suplai air;

e. Jenis komoditi yang ditanam.

(2) Penetapan besarnya IPAIR yang dimaksud ayat (1) Pasal ini dihitung berdasarkan rumusan dengan mempertimbangkan faktor-faktor sebagai berikut:
a. Faktor penerapan iuran;
b. Faktor orientasi pelayanan;
c. Dasar iuran per hektar;
d. Biaya pungut

Bagian Kedua

Tata Cara Pemungutan IPAIR

Pasal 6

(1) Pelaksanaan pemungutan IPAIR kepada Petani Pemakai Air dilakukan oleh Desa.

(2) Untuk pelaksanaan ketentuan dimaksud ayat(1) Pasal ini, Desa dikoordinir dan dibantu oleh Sekretaris Desa bekerja sama dengan P3A

$$
\begin{gathered}
\text { Bagian Ketiga } \\
\text { Penggunaan IPAIR } \\
\text { Pasal } 7
\end{gathered}
$$

(1) IPAIR yang akan dipungut adalah:
a. Tarif
IPAIR sepenuhnya dipergunakan untuk biaya operasi dan pemeliharaan irigasi.

b. Biaya pemungutan yang terdiri dari biaya administrasi dan upah pungut setinggi-tingginya $20 \%$ (dua puluh perseratus) dari besarnya IPAIR yang akan dipungut dan setinggitingginya $25 \%$ (dua puluh lima perseratus) dari besarnya tariff IPAIR

(2) Biaya operasi dan pemeliharaan irigasi dimaksud ayat (1) huruf a Pasal ini merupakan pengeluaran-pengeluaran untuk biaya operasi dan pemeliharaan jaringan irigasi utama, yaitu:
a. Pengoperasian pintu-pintuair;
b. Pengadaan bahan-bahan dan alat- alatkecil;
c. Pemeliharaan rutin;
d. Perbaikan kecil;
e. Peningkatan jaringan irigasi beserta bangunan pelengkapnya.

(3) Biaya administrasi dan upah pungut dimaksud ayat (1) huruf b Pasal ini ditetapkan dengan Keputusan Kepala Desa setinggi-tingginya $20 \%$ (dua puluh perseratus) dari realisasi penerimaan IPAIR, dengan ketentuan sebagai berikut:

a. Untuk biaya administrasi sebesar 5 $\%$ (lima perseratus);

b. Untuk upah pungut sebesar $15 \%$ (lima belas perseratus)

(4) Penerimaan dan pengeluaran IPAIR dimasukkan pada APBDes

Bagian Keempat

Pembebasan/keringanan IPAIR

Pasal 8

(1) Dengan tidak mengurangi ketentuan dimaksud Pasal 3 Peraturan Daerah ini, Petani Pemakai Air dapat diberi pembebasan atau keringanan dari kewajiban membayar IPAIR apabila sawahnya tidak menghasilkan dan/atau luas lahannya 0,1 (satu persepuluh) hektar kebawah.

(2) Untuk mendapatkan pembebasan atau keringangan IPAIR dimaksud ayat (1) Pasal ini, petani Pemakai Air harus mengajukan permohonan secara tertulis kepada Kepala Desa melalui P3A.

(3) Kepala Desa setelah mendapat saran pertimbangan dari P3A menetapkan pembebasan atau keringanan kepada PetaniPemakaiAir yang bersangkutan dari kewajiban membayar IPAIR.

Ekonomi, Sosial, dan Budaya | 1384 
Bagian Kelima

Biaya Tambahan

Pasal 9

Petani Pemakai Airyang terlambat membayar IPAIR dikenakan biaya tambahan sebesar $0,5 \%$ (setengah perseratus) untuk tiap bulan kelambatan dan setinggi-tingginya $3 \%$ (tiga perseratus) dari IPAIR yang terhutang.

\section{BAB 4}

\section{PELAKSANAAN IPAIR}

Pasal 10

(1) Peraturan Desa ini berlaku untuk seluruh Daerah Irigasi di Desa yang pelaksanaannya dilakukan secara bertahap.

(2) Pentahapan pelaksanaan IPAIR di daerah irigasi dimaksud ayat (1) Pasal ini ditetapkan Kepala Desa.

Pasal 11

(1) Pelaksanaan IPAIR oleh Pemerintah Desa dapat dilimpahkan P3A dengan menyampaikan laporan setiap masa tanam dan tahunan atau sewaktu-waktu apabila dipandang perlu mengenai pelaksanaan IPAIR kepada Kepala Desa.

\section{$\mathrm{BAB} 5$}

\section{PEMBINAAN DAN PENGAWASAN}

Pasal 12

Pembinaan dan Pengawasan terhadap pelaksanaan IPAIR dilakukan oleh Kepala Desa

\section{BAB 6}

\section{KETENTUAN LAIN-LAIN}

Pasal 13

Hal-hal yang belum diatur dalam Peraturan Desa ini sepanjang mengenai pelaksanaannya akan diatur lebih lanjut oleh KepalaDesa

\section{BAB 7}

\section{KETENTUAN PENUTUP}

Pasal 14

Peraturan Desa ini mulai berlaku pada tanggal diundangkan. Agar setiap orang dapat mengetahui, memerintahkan pengundangan Peraturan Desa ini dalam Lembaran Desa oleh Sekretaris Desa.

DITETAPKAN DI : Ndano

PADA TANGGAL :

KEPALA DESA NDANO

MULYADIN H.M. SYUKUR

Diundangkan di : Ndano

Pada tanggal :

SEKRETARIS DESA DNADO

MUKHLIS

LEMBARAN DESA NDANO TAHUN .... NOMOR .....

\section{KESIMPULAN}

Untuk menyelesaikan semua permasalahan yang dihadapi mitra, dilakukan kegiatan: pertama Memfasilitasi Menyusun Peraturan Desa yang mengatur kelembagaan P3A dan tatacara dan besarnya pungutan iuran pemakaian air; dan kedua Memberikan bimbingan teknis tentang tatacara penyusunan peraturan di desa. Dalam rangka meningkatkan

Ekonomi, Sosial, dan Budaya 1385 


\begin{tabular}{l}
\hline transfer ilmu pengetahuan khususnya \\
penyusunan peraturan di tingkat desa, \\
hendaknya kegiatan pengabdian pada \\
masyarakat digalakan, sehingga kemampuan \\
perangkat desa dan Badan Permusyawaratan \\
Desa di seluruh Kabupaten Bima dapat \\
ditingkatkan. Sekaligus dapat menyelesaikan \\
dan menyelaraskan produk hukum di tingkat \\
desa yang taat asas, taat aturan.
\end{tabular}

\section{UCAPAN TERIMA KASIH}

Dalam pelaksanaan Pemgambdian kepada masyarakat ini, saya mengucapkan terima kasih kepada semua pihak, antara lain, Lembaga Sekolah Tinggi Ilmu Hukum Muhammadiyah Bima, Pemerintah Desa Ndano Kecamatan Madapangga Kabupaten Bima, Masyarakat dan pihak-pihak lain yang berkontribusi dalam penyusunan pengabdian kepada masyarakat ini.

\section{REFERENSI}

Heri Rahman dkk, Deskripsi Komparatif Iuran Irigasi (IPI) di Saluran IndukDaerah Irigasi Jatiluhur Jawa Barat, Agriekonomika, volume 8 Nomor 2 Tahun 2019,

Ariff Purbantara dan Pujianto, 2019, Modul KKN Tematik Desa Membangun Pemberdayaan Masyarakat Desa, Kementerian Desa, Pembangunan
Daerah Tertinggal dan Transmigrasi Republik Indonesia, Jakarta

Peraturan Bupati Bima Nomor 41 Tahun 2018 tentang Pedoman Penyusunan Produk Hukum Daerah (berita Daerah Kabupaten Bima Tahun 2018 Nomor )

Peraturan Bupati Bima Nomor 2 Tahun 2020 tentang Daftar Kewenangan Desa Berdasarkan Hak Asal Usul dan Kewenangan Lokal Berskala Desa (Berita Daerah Kabupaten Bima Tahun 2020 Nomor 546)

Peraturan Pemerintah Nomor 43 Tahun 2016 Tentang Peraturan Pelaksanaan Undang-undang Nomor 6 Tahun 2014 tentang Desa

Peraturan Desa Ndano Kecamatan Madapangga Kabupaten Bima Nomor 5 Tahun 2020 tentang Pengesahan Daftar Hak Asal Usul dan Kewenangan Lokal Berskala Desa

Peraturan Desa Ndano Kecamatan Madapangga Kabupaten Bima Nomor 6 Tahun 2020 tentang Pengesahan Pendapatan dan Pungutan Desa

Peraturan Menteri Dalam Negeri Nomor 111 Tahun 2014 Tentang Pedoman Teknis Peraturan di Desa

Undang-undang Nomor 6 Tahun 2014 Tentang Desa 